\title{
NATURAL MONOPOLY IN RUSSIA: STATE REGULATION PROBLEMS
}

\author{
Sergey KIRSANOV ${ }^{1}$, Evgeny SAFONOV ${ }^{2}$, Sandra RAMIREZ ${ }^{3}$ \\ ${ }^{1}$ Russian State University for the Humanities in Domodedovo, St. Petersburg Institute of \\ Humanities, St. Petersburg, Russia \\ ${ }^{2}$ Russian State University for the Humanities in Domodedovo, Moscow, Russia \\ ${ }^{3}$ Center for Youth Projects of the Corporate University of JSC Russian Railways, \\ Moscow, Russia \\ Corresponding author e-mail: ksaimr@mail.ru
}

\begin{abstract}
The aim of the article is to reveal some aspects state regulation of natural monopoly in Russia, which are of paramount importance in economic and social life of the country. The optimal path to reforming the monopolized industries is currently a very topical question for Russia. The Russian government requires studying the foreign experience in this field and adapting it to the Russian conditions. Almost complete lack of transparency in the pricing of natural monopolies is one of the most important problems in Russia. In this connection, against the background of almost uncontrolled corruption in the country, the decision to increase tariffs for practically all services provided by monopolists, irrespective of the world prices for energy resources, causes distrust and just censures. The inefficient management of the state corporation Gazprom, a significant reduction in taxes transferred to the state budget, has not, until now, been the subject of thorough audit and critical analysis by the relevant government agencies. The Ministry of Energy does not attempt to reform the gas industry, for example, in the likeness of Scandinavian countries, where surprising results have been achieved in the operation of numerous energy suppliers. The increase of tax revenues to the country's budget and the improvement of the quality of life of the population depend on to the scope of reforms of the industry the state will carry out based on a combination of administrative and economic control measures. Methods of investigation used: analysis, synthesis, comparative analysis.
\end{abstract}

Keywords: Natural monopoly, state regulation, state corporation Gazprom.

\section{INTRODUCTION}

In recent decades, significant changes in the models of monopoly market organization have happened in many economically developed countries. The direction of reforms was determined by the need to eliminate the excessive government control of the state monopoly and to devise conditions for a competitive market. Such measures were intended to reduce the burden on the state budget. Arguably, the main transformation models of monopoly in foreign markets have already been developed. Russia may rely on the experience of a series of foreign countries. 
Nowadays, there are various opinions in the economic theory about the methods and limits of natural monopoly regulation. These issues are of a debatable nature. However, there is a common view that any regulation can harm not only the natural monopoly, but also the economy of the country, and society as a whole.

The products of natural monopolies are of high social importance, therefore, the effectiveness of state regulation of these industries directly depends on the functioning of the economy as a whole. It should be noted that to date there is no universal method of state regulation of natural monopoly in the world. Each method has both advantages and disadvantages. The choice depends on a number of factors and the main one is the level of the country's socio-economic development.

The study is aimed at finding approaches to improve the efficiency of the gas industry in Russia. The research methodology assumes a comparative analysis of the Russian and world experience of state regulation of natural monopolies and creation of a competitive environment in the gas industry. Methods of investigation used include analysis, synthesis, comparative analysis.

\section{STATE REGULATION OF NATURAL MONOPOLY IN RUSSIA}

A natural monopoly is commodity market conditions when the satisfaction of demand is more effective in terms of the absence of competition due to technological features of production; the goods produced by subjects of natural monopoly can not be replaced in consumption by other goods, as a result the demand in this market has lesser extent of dependence on the price change for this product than the demand for other types of goods (Belousova, 2016, p. 55).

Natural monopoly acts as a structure-forming element of the economy ensuring its stability, integrity and efficiency. The functioning of natural monopoly subjects has a significant impact on the final macroeconomic indicators, the social sphere and the security of the country.

The existence of a natural monopoly creates a dilemma: the production of products with lower costs may bring benefits for the society, which can be facilitated by the presence of a single firm in the industry. However, at the same time, the firm with the monopoly position has the opportunity to set higher prices and withdraw a part of the consumer's surplus. The goal of state regulation is to stimulate the monopoly to produce more products at a lower cost while refusing to establish monopoly prices.

The regulation of a natural monopoly can be carried out in various forms: from the direct establishment of prices for products to the sale of licenses with the right to operate in the industry while the monopoly is refusing to interfere in the operational management of the firm. Regulators should understand the extent to which consumers are dependent on the monopoly, how high demand elasticity is, whether there are close substitutes for the product, etc. First of all, regulatory authorities need to determine the object, issues and limits of regulation (Gorodetsky \& Pavlenko, 2013).

The authors consider some related problems. The state regulation of a natural monopoly is often beneficial for monopolists. The government grants a license for 
certain activities of these enterprises, thereby guaranteeing their monopoly position and removing the threat of potential competition.

It should be noted that the state regulation of a natural monopoly via special authorities has its disadvantages, including:

- biased nature of the regulatory bodies;

- high costs due to high labor intensity of the regulatory process;

- active intervention by regulators has an overwhelming effect on the firm administration;

- restrictions for structural reorganization of the industry;

- restrictions for the development of competition in industries that lose the features of natural monopoly (Sapir, 2004).

In this regard, the system of the state regulation of a natural monopoly itself needs to be controlled, in particular, by the antimonopoly authorities with a view to prevent slowdown in the development of the economy and the growth of the common wealth.

Gas pipelines are the object of the natural monopoly, but gas production, gas conversion process and sale could be carried out on a competitive basis. Likewise, electricity production is not a natural monopoly, the monopoly only refers to electricity transmission.

Let us consider the activities of a natural monopoly on the example of Gazprom. The public joint-stock company Gazprom (PJSC Gazprom) was registered by the Moscow Registration Chamber on February 25, 1993. The main economic activity of PJSC Gazprom is natural gas sales. The company also carries out other activities, including the services for organization of transportation and storage of gas, selling of gas condensate and refined oil and gas products, as well as production and selling of heat and electricity.

Gazprom is controlling $95 \%$ of Russian gas production, it provides $50 \%$ of Russia's energy needs. Gazprom is the largest gas company not only in Russia but also in the world, accounting for $25 \%$ of the world's gas production. The fields that Gazprom develops account for about $75 \%$ of all explored reserves of Russian gas and $23 \%$ of the world (The history of the country's gas industry development, 2006).

The specific nature of Gazprom is that it is both a producer and a supplier of energy resources with a powerful resource base and an extensive gas transportation infrastructure.

However, the capitalization of Gazprom in 2007-2015 declined from 330 to 54 billion dollars, or almost 6 times. In October 2015, Gazprom disappeared from the top 10 in the annual rating compiled by agency Platts, dropping from the 4th to the 43rd position for the year.

The error of Gazprom's top management consisted in underestimation of the "shale revolution" in the United States. In 2006 there was a gas "parity" in production between the Russian gas monopoly and the US companies, but at the end of 2016 the situation changed drastically (417 billion cubic meters from the Russian company against about 800 billion cubic meters from the USA). At the moment, the United States are implementing projects of export about 70 billion cubic meters of LNG (liquefied natural gas) to Europe, which is about a half of Gazprom's total export to Europe (Krichevsky, 2016). 
According to investment analysts, the archaic business strategy is not the reality of the modern world. The competition from American LNG may lead to a decrease of Gazprom's share in the European market and a failure to generate hundreds of billions of rubles in revenue. With equal volumes and price, the European consumer is more likely to prefer US gas to the Russian one.

Russian gas is supplied to Europe via pipelines, the productivity of which allows us to doubt their payback. So, in 2015, the load of the Nord Stream pipeline was $71 \%$ of the nominal capacity, according to experts. It should be noted that according to experts, the implementation benefits of the "Nord Stream - 2" are not obvious (Toporkov, 2017).

Gas supplies to Europe were 159 billion cubic meters in 2015, against 169 billion cubic meters in 2007. Gas supplies to the domestic market were 240 billion cubic meters in 2015, against 307 billion cubic meters in 2007. Thus, there is a drop of almost a quarter in less than 10 years (Milov, 2016).

In its statements for 2015 Gazprom announced a depreciation of the unfinished construction of the South Stream gas pipeline for more than 56 billion rubles (in addition to other "write-downs" of 157 billion rubles). This fact may indicate that Gazprom's management is unlikely to fully control investment and other costs. According to Krichevsky (2016), it should be noted that the deficit of the Russian state budget is about 3 trillion rubles in 2017.

In addition, the management of PJSC Gazprom asked the government to make an exception in the rule of paying state dividends. The decision of the board of Gazprom considers paying dividends considering the results of the last year, based on the net profit of 404 billion rubles. However, according to the government decree issued after the Gazprom board meeting, the profit of the gas monopoly is twice higher - over 805 billion rubles, according to the international financial reporting standards. According to experts, Gazprom will have to borrow for paying off the budget dividends in terms of international financial reporting standards (Krichevsky, 2016).

In 2017 the efficiency of the corporation continued to decline. According to the company's report, Gazprom's net profit for the first six months amounted to 17.4 billion rubles according to the Russian Accounting Standards (RAS), and that is 11.2 times lower that for the same period of the last year.

Table 1. Gazprom's Performance of 1 July 2017 (Joint Stock Company Gazeta.ru, 2017)

\begin{tabular}{|l|l|l|}
\hline No. & Indicators & $\begin{array}{l}\text { Results/performance } \\
\text { (compared to the previous year) }\end{array}$ \\
\hline 1 & Net profit, RAS & 17.4 billion rubles \\
\hline 2 & Revenues less VAT, excise taxes, etc. & $\begin{array}{l}2.089 \text { trillion rubles } \\
\text { (an increase by } 5.8 \%)\end{array}$ \\
\hline 3 & Gross margin & $\begin{array}{l}852.3 \text { billion rubles } \\
\text { (a drop by } 2.8 \%)\end{array}$ \\
\hline 4 & Profit on sales & $\begin{array}{l}191.8 \text { billion rubles } \\
\text { (a drop by 13.1 \%) }\end{array}$ \\
\hline 5 & Cost of sales & $\begin{array}{l}1.237 \text { trillion rubles } \\
\text { (an increase by } 12.6 \%)\end{array}$ \\
\hline
\end{tabular}




\begin{tabular}{|l|l|l|}
\hline 6 & Selling and marketing expenses & $\begin{array}{l}625 \text { billion rubles } \\
\text { (an increase by } 0.4 \%)\end{array}$ \\
\hline 7 & Management costs & $\begin{array}{l}35.5 \text { billion rubles } \\
\text { (an increase by } 7.6 \%)\end{array}$ \\
\hline 8 & Corporation tax & $\begin{array}{l}31.7 \text { billion rubles } \\
(2.3 \text { times drop) }\end{array}$ \\
\hline 9 & Long-term payments & $\begin{array}{l}2.027 \text { trillion rubles } \\
\text { (an increase by } 5 \%)\end{array}$ \\
\hline 10 & Short-term payments & $\begin{array}{l}1.632 \text { trillion rubles } \\
(\text { an increase by } 8.2 \%)\end{array}$ \\
\hline
\end{tabular}

Thus, the decrease of the Gazprom's net profit in 2017 is significant. It should be noted that in January-September of 2016 Gazprom's net profit under RAS fell 2.25 times, and 2.4 times for the entire 2016 .

It is interesting that one part of Gazprom's shares is not directly controlled by the state, but it is held by the joint-stock company Rosneftegaz", where significant funds from dividends on Gazprom shares have been accumulated in recent years. These dividends should have been transferred to the state budget, but remained in this company and are spent to purchase assets. Igor Sechin is the chairman of the board of directors of Rosneftegaz. At the same time, there is an increase in the number of employees in Gazprom: from 306,000 employees in 2000 to 450,000 employees in 2014, that is one and a half times higher (Milov, 2016).

In order to increase the efficiency of Gazprom, it is necessary to introduce careful spending control, transparent accounting and reporting on the tax payments, independent audit, and the development of new markets.

\section{WORLD EXPERIENCE OF STATE REGULATION OF NATURAL MONOPOLY}

In the developed market economies, the system of state regulation of monopolies was formed before the emergence of antimonopoly law. Constitutional obligation on the part of the state to protect the well-being, safety and health of its citizens is the basis of state regulation of private firms operating in conditions of natural monopoly.

The basic principles of regulation of natural monopoly are the following:

- the need for alternative sources of information on the subject of regulation;

- price regulation preference ahead of regulation of the profit rate of natural monopoly;

- full institutional separation of the regulated natural monopoly sector from the competitive spheres of the industry (Tugendhat, 1974, p. 88).

- In the developed market systems, the state regulation of natural monopolies has been constructed in different ways, but there are usually three main ways of regulating:

- introduction of special regulatory authorities, whose competence includes monitoring the activities of firms;

\footnotetext{
* $100 \%$ of Rosneftegaz shares belong to the state
} 
- direct management of state-owned enterprises;

- competitive access to the market.

At the end of the last century, Argentina, Great Britain, Japan, and others began to regulate after privatization. As a result, water supply, production and distribution of electricity, gas production and distribution, telephone communication were privatized. At the same time, the creation of a public regulation system of natural monopolies was a necessary step before the state enterprises of natural monopoly moved into private hands. Most countries have established special agencies, which are responsible for setting prices for privatized natural monopolies.

Regulation through property relations, which means direct management of state-owned enterprises, is the next means of public regulation of natural monopolies used in the countries with developed market economies. The greatest dissemination of this kind of state regulation of natural monopolies could be observed in Great Britain, France, Italy and other European countries, where energy, gas supply, ports, airports were completely monopolized by the state. The state acquired a number of industries that were unprofitable for private capital, thereby reconstructing them and creating conditions for economic growth in the country.

There is a general rule in selecting direct or indirect methods of economy regulation. It is the use of indirect methods of regulation in the equilibrium state of the economy and it is the use of direct methods with its substantial imbalance. Price formation is the direct method of state regulation of natural monopoly and it is advantageous. Common methods for regulating pricing are regulation based on the "rate of return", the most widely spread in the United States and regulation on the basis of tariff formulas "limit prices", used in Europe.

The natural monopoly is of paramount importance for the economy. The state regulation of a natural monopoly is often supplemented by measures of economic support (partial budget financing and budget lending) for ensuring the effectiveness of social production.

\section{MAIN AREAS OF STATE REGULATION OF NATURAL MONOPOLY}

The need for public regulation of the natural monopoly is caused by three main factors: the "failure" of the market, instability of equilibrium, the need for macroeconomic stabilization.

The natural monopoly regulation activity is based on the following setups:

- the lack of regulatory control by the state and the existence of competition ensures the right of the business entity to carte blanche in the conduct of business, as well as its better functioning in terms of efficiency;

- the choice in favour of state influence is justified by the fact that the state acts in the public interest, which may be at odds to the interests of the economic entity;

- the existence of state intervention as well as the interests of the business entity, is dictated by the accomplishment of interests of the public economy. 
Traditionally, the main areas of state regulation of natural monopolies include: price control, formation and maintenance of a competitive environment in natural monopoly industries, heading the tool of the monopoly rent redistribution, introduction and maintenance of unified international quality standards for products and services.

Like any phenomenon, the natural monopoly has both positive and negative consequences. We can define reduction in production costs, full use of the positive effect of the production scale, development and implementation of scientific and technical research and development $(\mathrm{R} \& \mathrm{D})$, the possibility of quality improving, accumulation of significant financial resources for further development, etc. as positive moments. However, there is a number of negative consequences: a significant understatement of the production volume and provided services, a lack of incentive to improve product quality and even a tendency to lower it in order to save costs while maintaining inflated prices, rigid dictatorship against competitors, inhibition of development of interconnected branches of the national economy, what is happening now in Russia.

Let us outline the following experience of the leading countries in regulation of the natural monopoly:

- wide use of public-private partnership that will allow improving the concession legislation and changing the situation in the gas industry for the better in a short time;

- structural isolation of the monopoly "core" as a key component of the natural monopoly and its organizational separation from potentially competitive links, which will create preconditions for civilized competition in Russia;

- transparency of the pricing process, which will allow excluding numerous abuses of monopolists in Russia by their exclusive position in the market of services.

\section{CONCLUSION}

Despite the image of a successful company, PJSC Gazprom is losing its markets and revenues with adverse effects on the state budget. The deficit of the state budget of Russia in 2017 amounted to about 3 trillion rubles. Nevertheless, the management of the state corporation continues to pay huge dividends to itself, which, under the conditions of the economic crisis in Russia, causes social tension. Many economists believe that a high degree of integrity of the Russian gas industry is objectively necessary and that Gazprom should stay a natural monopoly. In our opinion, this point of view is erroneous, comprehensive reform of the gas industry is required, which should be aimed at real competition. According to the world experience, gradual decentralization of regulation, emergence of new energy suppliers will lead to the emergence of a civilized market, increasing business efficiency and, as a result, revenues to the country's budget. 


\section{REFERENCES}

Belousova, N. I. (2016). Issues of the theory of State's regulation and identification of natural monopoly. In N. I. Belousova, E. M. Vasilyeva. M.: KomKniga, 2016. 320 p. (In Russian).

Gorodetsky, A., \& Pavlenko, Yu. (2013). Reforming Natural Monopoly. Issues of Economics, 1, 137138. (In Russian).

Joint Stock Company Gazeta.ru. (2017). Gazprom's net profit decreased 11.2 times. Retrieved from https://www.gazeta.ru/business/news/2017/08/14/n_10432748.shtml

Krichevsky, N. (2016). "Miracles of efficiency" of Gazprom. Retrieved from http://www.mk.ru/social/2016/05/11/chudesa-effektivnosti-gazproma.html (In Russian).

Milov, V. (2016). Top-management of state-owned companies: what they are paid for. Retrieved from http://www.rosbalt.ru/blogs/2016/02/17/1490998.html (In Russian).

Sapir, Zh. (2004). Natural monopoly: problems of definition and control. Problems of forecasting, 6 , 42-56. Retrieved from http://cyberleninka.ru/article/n/estestvennye-monopolii-problemyopredeleniya-i-kontrolya (In Russian).

The history of the country's gas industry development. (2006). Retrieved from http://www.studfiles.ru/preview/2474131/page:5/ (In Russian).

Toporkov, A. (2017). Gazprom is afraid of sanctions. Retrieved from http://vedomosti.profkiosk.ru/article.aspx?aid=573895

Tugendhat, K. (1974). International monopoly [Text]: translated from English. General edition and further [pp. 269-291], PhD in economics M. M. Maximova. Moscow: Progress, 1974. 293 p. (In Russian).

\section{AUTHORS' SHORT BIOGRAPHIES}

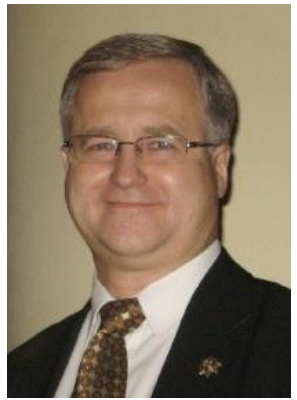

Sergey Kirsanov graduated from St. Petersburg State University with the degree in State and Municipal Management. In 2001 he became a candidate of economic sciences, and he is an associate professor since 2008.

S. Kirsanov has been working in the urban economy of St. Petersburg for a long time. He was three times elected a deputy to the Common Council Colpino. Currently he is an associate professor at the Russian State University for the Humanities (the branch in Domodedovo) and is the head of the State and Municipal Management Department in St. Petersburg Institute of Humanities.

Research interests: administrative and municipal reform, provision of public and municipal services, effectiveness of local government, modernization of housing and communal services. S. Kirsanov is the author and co-author of over 350 publications and books on housing and local government.

Sergey Kirsanov is a member of various establishments:

- member of tender committees for the civil services of Leningrad Region and ComptrollerGenera's Office of Leningrad Region

- member of the Council on Housing Policy and Housing of St. Petersburg and Leningrad Region

- member of the Board of Trustees at the non-commercial partnership "Sojkinskaja Shrine"

- S. Kirsanov has been awarded the medal "In Commemorationof the 300th Anniversary of St. Petersburg"; he is a knight of the Order of Alexander Nevsky "For Work and Fatherland".

Tel.: +792191398 69; e-mail: ksaimr@mail.ru 


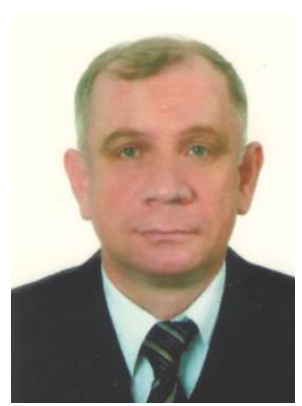

Evgeny Safonov graduated from Moscow Institute of Chemical Engineering in 1977. In 1987 he became a PhD in Economics and in 2007 - the Doctor of Economic Sciences. In 2009 he took the position of Professor at the Department of Public Administration. Since 2012 he is a Member of the Russian Academy of Natural Sciences.

Since 1999 to present he holds the position of the Director of SEI HPE Russian State University for the Humanities in Domodedovo.

Research interests: innovation strategy, commercialization of the results of intellectual activity, modernization of housing and utilities services, innovation in the provision of housing and utilities services. He is the author and co-author of over 150 publications and books on economics and management.

He is a deputy of Domodedovo City Council since 2006 up to now and was the Chairman of the Public Chamber of the city district Domodedovo in 2005-2017.

Tel.: +7910 45146 82; e-mail: ensafonov_55@mail.ru

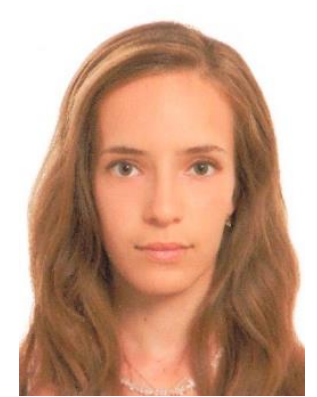

Sandra Maria Ramirez Tumanian graduated from the Department of State and Municipal Management, the Finance University under the Government of the Russian Federation. In 2013 she obtained a Master Degree at the Moscow State Institute of International Relations of the Ministry of Foreign Affairs of the Russian Federation at the program "International Management in the Field of Railway Transport".

Currently Sandra is the chief specialist of the Center for Youth Projects of the Corporate University of JSC Russian Railways.

Research interests: efficiency of state-owned companies, mentality modernization of the management of state-owned companies and authorities in Russia, effective management, increase of labor productivity in the authorities and state-owned companies.

Tel.: + 791754141 45; e-mail: ramirez.sandra@mail.ru 